\title{
A kinetic model for hydrolysis of whey proteins by cardosin A extracted from Cynara cardunculus
}

\author{
Rui M. Barros, F. Xavier Malcata * \\ Escola Superior de Biotecnologia, Universidade Católica Portuguesa, Rua Dr. António Bernardino de Almeida, P-4200-072 Porto, Portugal
}

Keywords: Plant protease; Enzyme; Dairy foods; Reaction rate

\begin{abstract}
The enzymatic hydrolysis of the major whey proteins, namely $\beta$-lactoglobulin $(\beta-\mathrm{Lg})$ and $\alpha$-lactalbumin $(\alpha-\mathrm{La})$, was experimentally studied using whey as substrate; an aspartic protease (cardosin A), previously extracted from the flowers of Cynara cardunculus and purified by gel filtration and ion exchange chromatographies, was used for this purpose. Sweet whey was incubated for $24 \mathrm{~h}$ at various enzyme:substrate ratios, at controlled $\mathrm{pH}(5.2$ and 6.0$)$ and temperature $\left(55^{\circ} \mathrm{C}\right)$; the hydrolyzates were assayed by gel permeation chromatography and electrophoresis. A mechanistic model was proposed for the kinetics, which basically leads to a double-substrate, single-enzyme Michaelis-Menten rate expression containing four adjustable parameters; these parameters were estimated by applying multiresponse, nonlinear regression analysis to the experimental data, so that the model would yield good fits. The best estimates obtained for $K_{\mathrm{m}}$ were markedly lower for $\alpha$-La than for $\beta$ - $\mathrm{Lg}$, so cardosin A shows a higher affinity for $\alpha$-La than for $\beta$-Lg. The experimental results also suggest that $\beta$ - $L g$ is rather resistant to enzyme-mediated hydrolysis under all experimental conditions tested. The highest activity (measured by $k_{\mathrm{cat}}$ ) of cardosin A was recorded toward $\alpha$-La (i.e. $0.013 \mathrm{~s}^{-1}$ ) at $\mathrm{pH}$ 5.2. Furthermore, the specificity ratio $\left(k_{\mathrm{cat}} / K_{\mathrm{m}}\right)$, obtained toward each whey protein, indicated that cardosin A possesses a higher catalytic efficiency for hydrolysis of $\alpha$-La than of $\beta$ - $\mathrm{Lg}$; the highest value for this ratio was recorded for $\alpha$-La at $\mathrm{pH} 5.2$, and was close to that reported elsewhere for cardosin A acting on caseins and casein-like substrates.
\end{abstract}

\section{Introduction}

Aspartic proteases (EC 3.4.23), also known as acid proteases or aspartyl proteinases, are a widely distributed subfamily of proteolytic enzymes, which belong to the endopeptidase family and have been found in vertebrates, plants, viruses and retroviruses. Recent studies (Faro, 1991; Faro, Veríssimo, Lin, Tang, \& Pires, 1995; Heimgartner et al., 1990; Veríssimo et al., 1996) have shown that it is possible to extract and purify two aspartic proteases, namely cardosins $\mathrm{A}$ and $\mathrm{B}$, from the flowers of the thistle, Cynara cardunculus; these enzymes are characterized by somewhat related amino acid sequences - to a degree of $73 \%$ similarity (Vieira et al., 2001). Crude aqueous extracts of the flowers of C. car-

\footnotetext{
${ }^{*}$ Corresponding author. Tel.: +351-22-5580004; fax: 351-225090351.

E-mail address: xmalcata@esb.ucp.pt (F. Xavier Malcata).
}

dunculus have for decades been used in Portugal as a successful rennet for cheesemaking using ewe's milk. Cardosin A is more abundant than cardosin B in $C$. cardunculus; the relative amount of the former is ca. $75 \%$ of the total, on a protein mass basis (Barros \& Malcata, 2002; Ramalho-Santos et al., 1997; Veríssimo, Esteves, Faro, \& Pires, 1995). The same authors reported that cardosin A consists of two polypeptide subunits, with apparent molecular weights of 31 and $15 \mathrm{kDa}$; it possesses a preference for peptide bonds next to hydrophobic side chains, and it is similar to chymosin (at least at $\mathrm{pH} 4.7$ and $37^{\circ} \mathrm{C}$ ) in terms of specificity.

Increasing economic and environmental pressures during recent decades, to upgrade whey produced as a by-product of the cheesemaking industry, have urged technological developments in this field. Novel applications, that bring about high added value to whey, should focus on the most abundant whey proteins (i.e. $\beta-\mathrm{Lg}$ and $\alpha-\mathrm{La})$. These whey proteins are functionally and 
nutritionally superior to most other proteins of common foods, owing to their favourable amino acid composition, especially in terms of Cys, Met, Lys and Trp residues. Selective hydrolysis of $\beta-\mathrm{Lg}$ and $\alpha$-La by proteases, preceding or subsequent to thermal treatment, appears promising; potential end-uses encompass formulation of special diets, or manufacture of more easily uptaken nitrogen sources for fermentation broths.

Studies encompassing purified cardosin A, using either (natural) short or synthetic peptides as model substrates (Veríssimo et al., 1995), can be described via simple kinetic expressions; conversely, proteolysis of mixtures of proteins by action of a proteolytic enzyme mixture would lead to quite complex global models. Recently, a general kinetic model for the action of a mixture of cardosins $\mathrm{A}$ and $\mathrm{B}$, acting on major whey proteins, has been proposed and successfully fitted to experimental data (Barros \& Malcata, 2002).

Even though the action of crude extract of $C$. cardunculus, which contains a mixture of cardosins $\mathrm{A}$ and B among other proteins (including enzymes), on whey proteins and on caseins has been reported (Barros \& Malcata, 2002; Sousa \& Macata, 1998), no specific data pertaining to the independent action of each of those two aspartic proteinases on whey proteins have, to our knowledge, been published to date. The objective of this research work was thus to study the action of the dominant proteinase of the crude extract, i.e. cardosin A, after preliminary separation and purification, and to compare the results with those previously reported for the crude extract. Furthermore, this study was intended to ascertain the effects of two easily manipulated operational conditions, namely $\mathrm{pH}$ and enzyme concentration, on the simultaneous hydrolysis of $\beta-\mathrm{Lg}$ and $\alpha$-La brought about by purified cardosin A. A kinetic model was duly postulated, and the relevant kinetic parameters therein were estimated and compared with corresponding values available in the literature.

\section{Materials and methods}

\section{Feedstocks and chemicals}

Sweet whey was obtained as a by-product of rennetbased cheesemaking using standard cow's milk, and was lyophilized prior to storage. Pure whey proteins of bovine origin (i.e. $\alpha$-La, $\beta$-Lg and bovine serum albumin, BSA) were purchased from Sigma (St. Louis MO, USA). Azocasein, ammonium persulfate, TEMED $\left(N^{\prime} N^{\prime} N^{\prime} N\right.$-tetramethylethylenediamine) and molecular weight standards for Phast ${ }^{\circledR}$ electrophoresis (BSA: 66 $\mathrm{kDa}$, ovalbumin: $45 \mathrm{kDa}$, glyceraldehyde-3-phosphate dehydrogenase: $36 \mathrm{kDa}$, carbonic anhydrase: $29 \mathrm{kDa}$, trypsinogen: $24 \mathrm{kDa}$, trypsin inhibitor: $20 \mathrm{kDa}$ and $\alpha$ -
La: $14.2 \mathrm{kDa}$ ) were all purchased from Sigma. Sodium dihydrogen phosphate monohydrate and disodium hydrogen phosphate dihydrate, citric acid monohydrate, trichloroacetic acid (TCA) and extra pure sodium azide were obtained from Merck (Darmstadt, Germany). Molecular weight standards for FPLC (aldolase: 158 $\mathrm{kDa}$, BSA: $67 \mathrm{kDa}$, ovalbumin: $43 \mathrm{kDa}, \beta-\mathrm{Lg}$ : $36 \mathrm{kDa}$, $\alpha$-La: $14.4 \mathrm{kDa}$ and ribonuclease: $13.7 \mathrm{kDa}$ ) and blue dextran were purchased from Pharmacia LKB Biotechnology (Uppsala, Sweden). A mixture of molecular weight standards for Tricine-SDS-PAGE (viz. phosphorylase B: $94 \mathrm{kDa}$, BSA: $67 \mathrm{kDa}$, ovalbumin: $43 \mathrm{kDa}$, carbonic anhydrase: $30 \mathrm{kDa}$, soybean trypsin inhibitor: $20.1 \mathrm{kDa}$ and $\alpha$-La: $14.4 \mathrm{kDa}$ ), sodium dodecyl sulfate (SDS), $\beta$-mercaptoethanol and Tricine ( $N$-tris(hydroxymethyl)methyl-glycine) were all purchased from BioRad (Hercules CA, USA). The water used in the preparation of all solutions was previously deionized and distilled. The solvents used were analytical grade or better, and were employed without further purification.

\section{Extraction and purification of enzyme}

The crude enzyme extract was prepared at room temperature by macerating ca. $7 \mathrm{~g}$ of stylets and stigma of dried flowers of C. cardunculus in $70 \mathrm{ml}$ of $100 \mathrm{mM}$ sodium citrate buffer ( $\mathrm{pH}$ 3.0), as described by Faro (1991). The aqueous extract thus obtained was centrifuged at $10,000 \mathrm{~g}$ for $5 \mathrm{~min}$ at $4{ }^{\circ} \mathrm{C}$. A gel filtration chromatography column (Sephacryl S-200 HR 16/60, from Pharmacia) was loaded with $5 \mathrm{ml}$ of the resulting supernatant in order to recover the peak accounted for by cardosins $\mathrm{A}$ and $\mathrm{B}$, as described by Barros and Malcata (2002). This step was repeated as many times as necessary to obtain preparative amounts of partially purified extract prior to lyophilization.

Following the gel filtration step, the partially purified extract was reconstituted in $1 \mathrm{ml}$ of Tris- $\mathrm{HCl}$ buffer $(\mathrm{pH}$ 7.6), and $20 \mathrm{mg}$ of extract was subject to further purification by (weak) anion-exchange chromatography (column DEAE, i.d. 2.5 and length $30 \mathrm{~cm}$, from Bio$\mathrm{Rad})$, using a linear gradient of $0-0.5 \mathrm{M} \mathrm{NaCl}$ in $250 \mathrm{ml}$ of $0.2 \mathrm{M}$ Tris- $\mathrm{HCl}$ buffer ( $\mathrm{pH}$ 7.6), at a flow rate of 1.2 $\mathrm{ml} / \mathrm{min}$. Such a chromatographic procedure differs from that used by Veríssimo et al. (1996), who employed a Superdex 200 gel filtration column, followed by an ionexchange Mono- $Q$ column. This chromatographic step was repeated as many times as needed to yield preparative amounts of cardosin A. The active fraction of cardosin A was duly collected, and dialyzed for $48 \mathrm{~h}$ at 4 ${ }^{\circ} \mathrm{C}$ against a large volume of deionized water (so as to remove Tris and citrate), using dialysis tubing with a MW cutoff of $10 \mathrm{kDa}$ (Sigma). The pure cardosin A was finally frozen at $-20{ }^{\circ} \mathrm{C}$ and lyophilized. After collection, the presence of (only) cardosin A was confirmed by electrophoresis, using Phastgel-high density gels. 


\section{Determination of protein content}

The total protein content of pure cardosin A was determined via the Micro Protein determination kit A690 (Sigma). Assays were carried out in triplicate, and their averages were taken as datum points.

\section{Determination of proteolytic activity}

The procedure followed to measure the proteolytic activity of pure cardosin A was described by Lamas, Barros, Balcǎo, and Malcata (2001), and consists of slight modifications of the method initially proposed by Tomarelli, Charney, and Harding (1949) that involves digestion of azocasein (a casein derivative containing a dinitrogenated arylamine chromophore); quantification of the proteolytic activity was based on the amount of peptides released, as monitored by absorbance units (AU) at $440 \mathrm{~nm}$. For this purpose, lyophilized cardosin A was dissolved in $0.1 \mathrm{M}$ phosphate buffer $(\mathrm{pH}$ 6.0) to produce an enzyme solution at a concentration of $0.01 \mathrm{~g} /$ $\mathrm{ml}$; a $0.01 \mathrm{ml}$-aliquot of the solution was then mixed with $0.5 \mathrm{ml}$ of $2 \%(\mathrm{w} / \mathrm{v})$ azocasein, and incubated at 25 ${ }^{\circ} \mathrm{C}$ for $10 \mathrm{~min}$; the reaction was finally quenched by addition of $0.5 \mathrm{ml}$ of cold $5 \%(\mathrm{w} / \mathrm{v})$ aqueous TCA. Unhydrolyzed proteins were then removed by centrifugation for $10 \mathrm{~min}$ (using a Model Universal 32-refrigerated centrifuge, from Hettich, Tuttlingen, Germany) at $10,300 \mathrm{~g}$ and $4{ }^{\circ} \mathrm{C}$. To intensify the azo-associated colour, $1 \mathrm{ml}$ of the supernatant was mixed with $1 \mathrm{ml}$ of $0.5 \mathrm{M}$ aqueous $\mathrm{NaOH}$. A blank was prepared in a similar fashion, but with the addition of TCA before addition of the enzyme. The assays were carried out in triplicate, and their averages were taken as datum points. The proteolytic activity of cardosin A, expressed as variation of absorbance at $440 \mathrm{~nm}(\Delta \mathrm{Abs}$ per gram of protein per minute) was $1.27 \pm 0.12 \mathrm{AU} / \mathrm{g} / \mathrm{min}$ at startup, and $1.09 \pm 0.10 \mathrm{AU} / \mathrm{g} / \mathrm{min}$ by $24 \mathrm{~h}$ of incubation under the same experimental conditions. Statistical analysis of the data was carried out using Student's $t$ tests for comparison of means, at a level of significance of $P \leqslant 0.05$ (Excel $^{\mathrm{TM}}$ software, from Windows 95 v. 7.0); no significant differences were thus found in terms of proteolytic activity throughout hydrolysis.

\section{Determination of coagulating activity}

The clotting activity was determined according to the procedure described in IDF-157 (Anon, 1992). The lyophilized enzyme $(0.05 \mathrm{~g})$ was dissolved in $10 \mathrm{mM}$ aqueous $\mathrm{CaCl}_{2}$ (pH 6.5); the clotting time was measured using $0.2 \mathrm{ml}$ of the enzyme solution mixed with $2 \mathrm{ml}$ of reconstituted milk. One rennet unit (RU) was defined as the amount of crude extract needed to coagulate $10 \mathrm{ml}$ of reconstituted, low-heat skim milk powder (NI$\mathrm{LAC}^{\mathrm{TM}}$, from NIZO, Ede, The Netherlands) at $30^{\circ} \mathrm{C}$ in
$100 \mathrm{~s}$ (Berridge, 1952). The assays were carried out in triplicate, and their averages were used as datum points. The coagulation activity of cardosin A was $442 \pm 10$ and $423 \pm 11 \mathrm{RU} / \mathrm{g}$, by 0 and $24 \mathrm{~h}$, respectively, of incubation under the same experimental conditions. Statistical analysis of the data showed that no significant $(P>0.05)$ differences were found in terms of the coagulant activity throughout hydrolysis.

\section{Performance of enzymatic hydrolysis}

The enzymatic reactions were performed batchwise, and employed variable amounts of cardosin $\mathrm{A}$ and substrate up to the same overall volume of reaction medium, according to Table 1. For the experiments encompassing variable enzyme concentration at a constant substrate concentration, three aqueous solutions $(50 \mathrm{ml})$ were used, containing a total of $5 \%(\mathrm{w} / \mathrm{v})$ whey proteins, obtained directly from freeze-dried whey, in $100 \mathrm{mM}$ sodium citrate buffer ( $\mathrm{pH} 5.2$ and 6.0). For the experiments encompassing variable substrate concentration at a constant enzyme concentration, three aqueous solutions $(50 \mathrm{ml})$ were used, containing a total of $2.5 \%, 5 \%$ and $10 \%(\mathrm{w} / \mathrm{v})$ whey proteins in $100 \mathrm{mM}$ sodium citrate buffer ( $\mathrm{pH} 5.2$ and 6.0).

All reactions were performed at $55^{\circ} \mathrm{C}$ for $24 \mathrm{~h}$, in a water bath equipped with an orbital shaker set at 100 rpm. Hydrolysis of the main proteins was checked by tricine-SDS-PAGE (16.5\%). The kinetics of disappearance of $\beta$-Lg and $\alpha$-La were monitored by FPLC using a Superose 12 column HR 10/30 (Pharmacia), as described previously by Barros, Ferreira, Silva, and Malcata (2001). All experiments were run in parallel with a control, which used similar conditions but without enzyme, so as to confirm whether hydrolysis was only a result of the action of cardosin A added (as happened), and not of any adventitious enzymes in the whey substrate (e.g. chymotrypsin). Furthermore, azide $\left(\mathrm{NaN}_{3}\right)$ was added, in all experiments, to a final concentration of $0.1 \%(\mathrm{w} / \mathrm{v})$, so as to inhibit microbial growth.

Table 1

Experimental layout for the batchwise hydrolysis of whey protein, catalyzed by cardosin A

\begin{tabular}{lllll}
\hline Variable & $\begin{array}{l}\text { Cardosin } \\
\mathrm{A}(\mathrm{mg})\end{array}$ & $\begin{array}{l}\text { Whey } \\
\text { protein } \\
(\mathrm{mg})\end{array}$ & $\begin{array}{l}\text { E/S ratio } \\
\left(\mathrm{mg}_{\text {protein }} /\right. \\
\left.\mathrm{mg}_{\text {whey protein }}\right)\end{array}$ & $\begin{array}{l}\text { Buffer } \\
\text { volume } \\
(\mathrm{ml})\end{array}$ \\
\hline Substrate & 1 & 125 & $1 / 125$ & 50 \\
& 1 & 250 & $1 / 250$ & 50 \\
& 1 & 500 & $1 / 500$ & 50 \\
Enzyme & 0.5 & 250 & $0.5 / 250$ & 50 \\
& 1 & 250 & $1 / 250$ & 50 \\
& 2 & 250 & $2 / 250$ & 50 \\
Control & - & 250 & - & 50 \\
\hline
\end{tabular}

E: enzyme; S: substrate. 


\section{Mechanistic modelling}

Cardosin A will hereafter be denoted as E. Since whey is composed of two different substrates, i.e. $\alpha$-La and $\beta-\mathrm{Lg}$, hereafter denoted as $S_{\alpha}$ and $S_{\beta}$, respectively, the following overall chemical scheme should accurately describe the reaction phenomena:

$\mathrm{S}_{\alpha}+\mathrm{E} \stackrel{K_{\mathrm{m} \alpha}}{\rightleftarrows} \mathrm{E} \cdot \mathrm{S}_{\alpha} \stackrel{k_{\text {cat } \alpha}}{\longrightarrow} \mathrm{E}+\mathrm{P}_{\alpha}$

$\mathrm{S}_{\beta}+\mathrm{E} \stackrel{K_{\mathrm{m} \beta}}{\rightleftarrows} \mathrm{E} \cdot \mathrm{S}_{\beta} \stackrel{k_{\text {cat } \beta}}{\longrightarrow} \mathrm{E}+\mathrm{P}_{\beta}$

where $K_{\mathrm{m}, i}$ represents the Michaelis-Menten parameter for cardosin A and substrate $\mathrm{S}_{i}$, and $k_{\mathrm{cat}, i}$ represents the intrinsic kinetic constant associated with formation of product $\mathrm{P}_{i}$ catalyzed by cardosin $\mathrm{A}$. For the sake of mathematical simplicity, quasi-equilibrium conditions for the enzyme-substrate complexes were assumed. The resulting rate expression corresponds to a double-substrate, single-enzyme Michaelis-Menten model, which may be written as:

$$
\begin{gathered}
-\frac{\mathrm{d} C \alpha}{\mathrm{d} t}=\left(\frac{k_{\mathrm{cat} \alpha * C_{\mathrm{E}} * \frac{C_{\alpha}}{K_{\mathrm{m} \alpha}}}}{1+\frac{C_{\alpha}}{K_{\mathrm{m} \alpha}}+\frac{C_{\alpha}}{K_{\mathrm{m} \beta}}}\right), \\
-\frac{\mathrm{d} C \beta}{\mathrm{d} t}=\left(\frac{k_{\operatorname{cat} \beta * C_{\mathrm{E}}{ }^{*} \frac{C_{\beta}}{K_{\mathrm{m} \beta}}}}{1+\frac{C_{\alpha}}{K_{\mathrm{m} \alpha}}+\frac{C_{\alpha}}{K_{\mathrm{m} \beta}}}\right),
\end{gathered}
$$

where $C_{i}$ denotes the molar concentration of substrate $\mathrm{S}_{i}$ and $t$ denotes reaction time.

The lumped constants, $V_{\max , i}$, defined as

$V_{\max , i}=k_{\mathrm{cat}, i} * C_{\mathrm{E}}$,

where left as adjustable parameters, together with $K_{\mathrm{m} \alpha}$ and $K_{\mathrm{m} \beta}$.

A numerical method, based on finite differences, was employed to integrate Eqs. (1) and (2) in the time variable. The four kinetic parameters of this model were estimated by multiresponse nonlinear regression analysis, using the General REGression package (GREG) by Caracotsios, Stewart, and Sorensen (1985); this software package performs nonlinear regression analysis of multiresponse data, using small differences as approximants of the derivatives of the objective function with respect to each parameter. The objective function is minimization of $N * \ln \{|\mathbf{R}|\} 2$, where the auxiliary matrix is defined as $\mathbf{R} \equiv \mathbf{Z}^{T} \mathbf{Z}$ and where $\mathbf{Z}$ is the $M \times N$ matrix of the residuals obtained at each of the $M$ measurements $(M=2: \alpha-\mathrm{La}$ and $\beta-\mathrm{Lg}$ concentrations $)$ for each of the $N$ experiments $(N=8$ : number of reaction times). This model was simultaneously fitted to data pertaining to both the $\alpha$ - $\mathrm{La}$ and $\beta-\mathrm{Lg}$ concentrations in each sample, encompassing five enzyme-substrate ratios, independently generated via changing initial enzyme concentration or initial substrate con- centration, at either of two different $\mathrm{pH}$ values (but at the same temperature).

\section{Results and discussion}

\section{Influence of enzyme and substrate concentration}

The evolution of the concentrations of the major whey proteins, $\beta-\mathrm{Lg}$ and $\alpha$-La, incubated at different enzyme and substrate concentrations, at $\mathrm{pH} 5.2$ and 6.0, is plotted in Figs. 1 and 2, respectively. The hydrolysis rates of $\alpha$-La (see Figs. 1(a) and 2(a)) were significantly higher than those of $\beta-\mathrm{Lg}$ (see Figs. 1(c) and 2(c)). Larger initial amounts of cardosin A led to a much faster degradation of $\alpha$-La (i.e. higher enzyme concentrations decreased reaction time for a total conversion of that substrate), as expected. The fastest reaction was obtained with the highest enzyme to substrate ratio $(\mathrm{E} / \mathrm{S}=4 / 500)$ at $\mathrm{pH} 5.2$; under these conditions, $\alpha$-La was completely broken down to peptides by $2 \mathrm{~h}$ (see Fig. 1(a)). Inspection of Figs. 1(c) and 2(c) indicates that the hydrolysis of $\beta-\mathrm{Lg}$ was not significantly influenced by the increase in enzyme concentration (i.e. the $\beta-\mathrm{Lg}$ concentration remained essentially unaltered for $24 \mathrm{~h}$ ).

With regard to the substrate concentration effect, $\alpha$ La was completely broken down to peptides (Figs. 1(b) and $2(b))$, whereas a major portion of $\beta$ - $\mathrm{Lg}$ remained essentially intact (Fig. 1(d) and 2(d)). This observation may be a consequence of the low affinity of cardosin A for $\beta$ - Lg rather than of the competitive inhibition by $\alpha$ $\mathrm{La}$, because the degree of hydrolysis of $\beta-\mathrm{Lg}$ was essentially the same, irrespective of the actual degree of hydrolysis of $\alpha$-La. Inspection of Figs. 1 and 2 also indicates that the hydrolysis profile of each of those major whey proteins is essentially independent of the initial concentrations of either substrate.

\section{Influence of $\mathrm{pH}$}

The change in conformation of the whole substrate protein, as well of the enzyme itself, effected by changes in $\mathrm{pH}$ may influence the access of a protease to particular pairs of amino acid residues within the substrate structure. According to Campos, Guerra, Aguilar, Ventura, and Camacho (1989), the optimum $\mathrm{pH}$ for the proteolytic activity of $C$. cardunculus crude extract is 5.7 at $37^{\circ} \mathrm{C}$, when casein is employed as substrate. In our case, the more noteworthy result of the hydrolysis profiles, when $\mathrm{pH}$ was varied from 5.2 to 6.0 , was a slight decrease in the reaction rate, especially for $\alpha$-La; almost no alterations of the rate of hydrolysis of $\beta-\mathrm{Lg}$ were observed. Barros and Malcata (2002) have shown that crude mixtures containing cardosin A (and cardosin B, among other proteins) possess higher affinity for $\alpha$-La at $\mathrm{pH} 5.2$ 

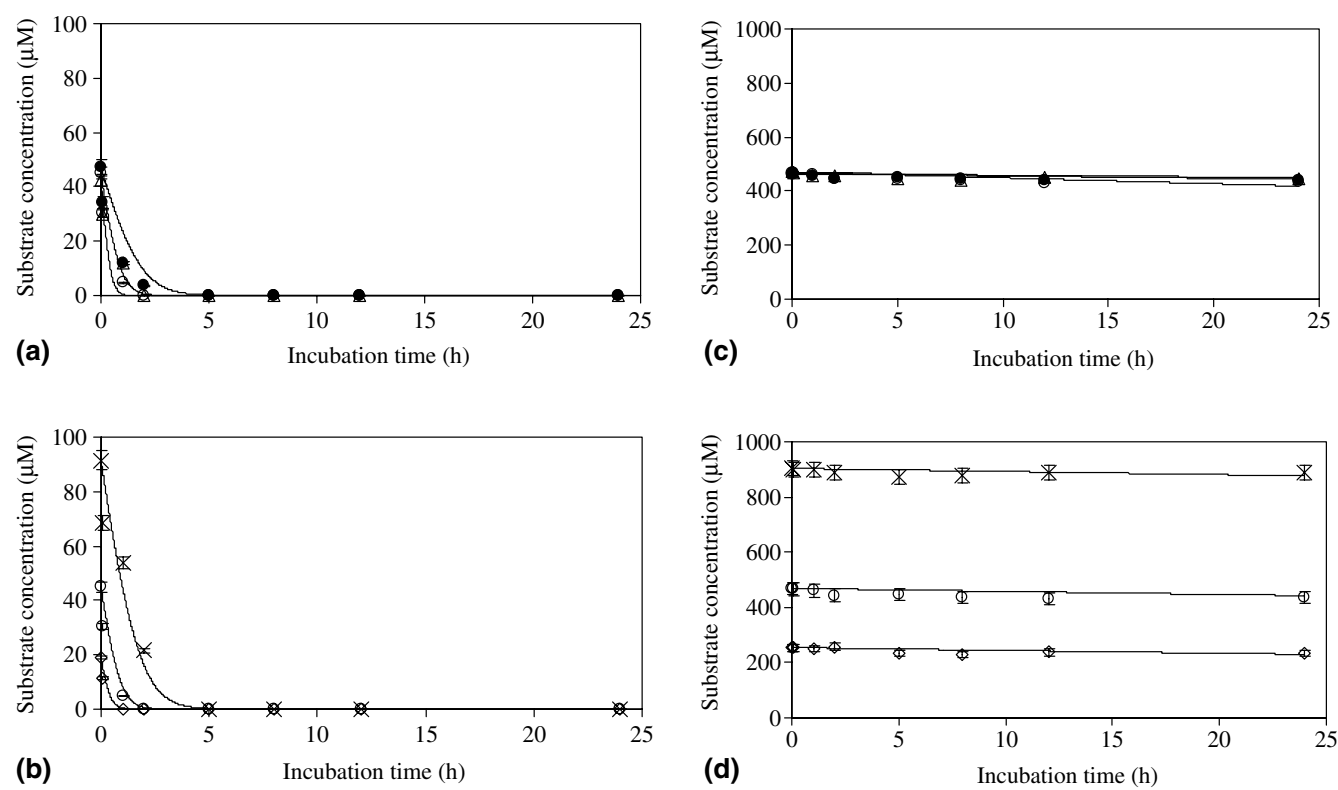

Fig. 1. Evolution, with time, of the concentration of $\alpha-\mathrm{La}(\mathrm{a}, \mathrm{b})$ and of $\beta-\mathrm{Lg}(\mathrm{c}, \mathrm{d})$ as substrates, at $\mathrm{pH} 5.2$ and $55^{\circ} \mathrm{C}$, at various initial E/S ratios: $1 / 500 ; \bigcirc, 2 / 500 ; \triangle, 4 / 500 ; \diamond, 2 / 250 ;$ and $\times, 2 / 1000$. The experimental data are represented as discrete points (with bars for their standard errors), and the theoretical values as solid lines $(-)$.

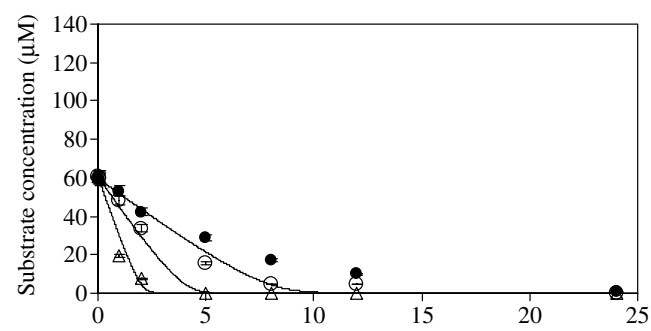

(a)
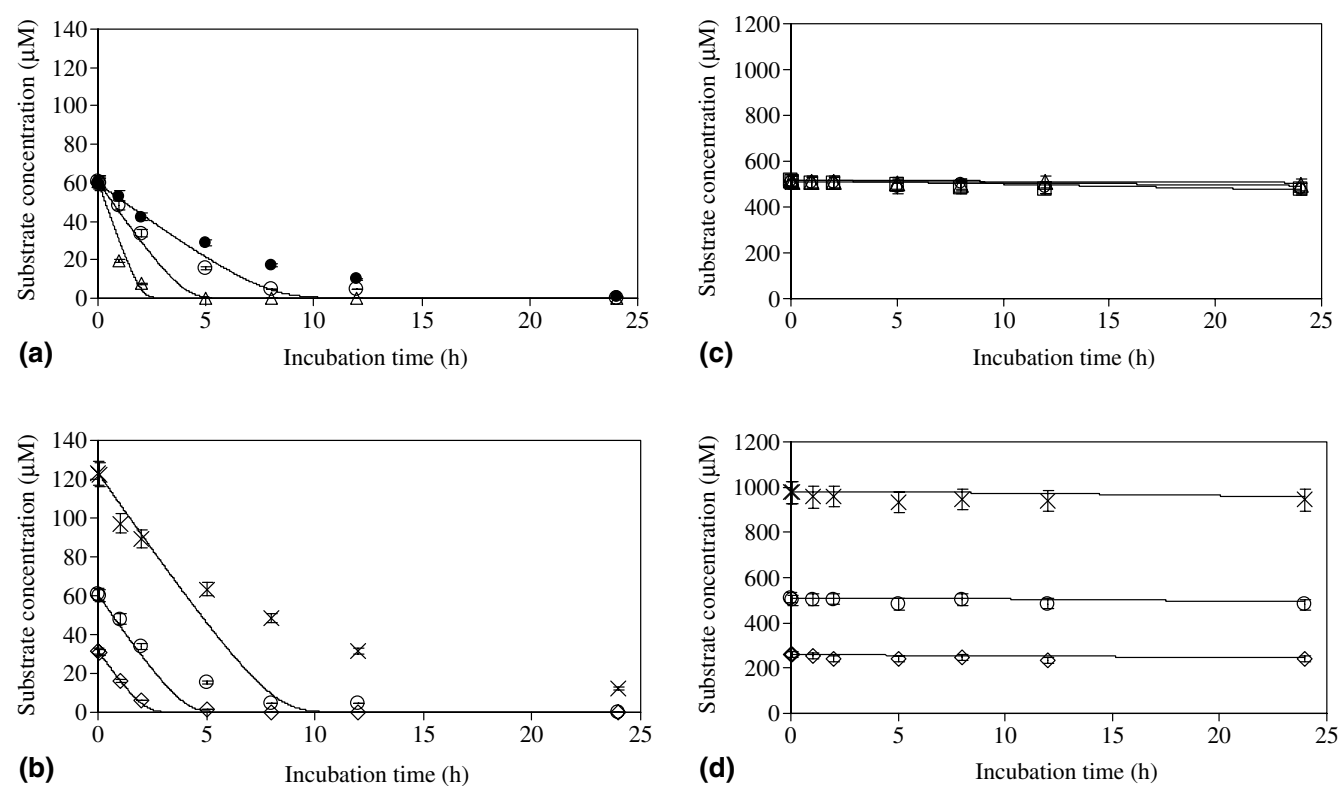

Fig. 2. Evolution, with time, of the concentration of $\alpha-\mathrm{La}(\mathrm{a}, \mathrm{b})$ and of $\beta-\mathrm{Lg}(\mathrm{c}, \mathrm{d})$ as substrates, at $\mathrm{pH} 6.0$ and $55^{\circ} \mathrm{C}$, at various initial $\mathrm{E} / \mathrm{S}$ ratios: $1 / 500 ; \bigcirc, 2 / 500 ; \triangle, 4 / 500 ; \diamond, 2 / 250$; and $\times, 2 / 1000$. The experimental data are represented as discrete points (with bars for their standard errors), and the theoretical values as solid lines $(-)$.

than at $\mathrm{pH} 6.0$; they claimed that a difference in protein structure might be responsible.

\section{Estimation of kinetic parameters}

The best fits of the postulated model to the experimental data, pertaining to the catalytic action of cardosin A on the two major whey proteins in the presence of each other, are depicted in Figs. 1 and 2. Visual in- spection of these figures indicates that the fits are good for all sets of data throughout the entire reaction timeframe; the $t$-ratios, i.e. the ratio of the standard error of each parameter estimate to the actual parameter estimate (results not shown), were also well below unity, which statistically confirms the goodness of those fits. According to van Boekel (1996), one advantage of multiresponse modelling (in addition to increased number of degrees of freedom, and hence narrower 
inference intervals) is the use of the information conveyed by various responses in the generation of more accurate parameter estimates, and thus more realistic model fits. Furthermore, overparameterization would otherwise have limited the validity of the statistical analysis, with the likely possibility of unrealistic parameter estimation, in view of their physicochemical meaning. On the other hand, oversimplified, lumped substrate kinetic approaches would produce poor modelling, with a consequently narrow application range.

The set of starting parameter estimates considerably affected the speed and the degree of convergence to the final estimates; if poor starting estimates were used, GREG would sometimes satisfy a convergence criterion (minor change in the residual sum of squares between successive iterations), but the final parameter estimates would be very poor, and the associated residual sum of squares would sometimes be unacceptable; in other cases, the final parameter estimates would produce reasonable residuals, yet they would be physically unrealistic. The associated kinetic parameters, namely $K_{\mathrm{m}}, k_{\text {cat }}$ and $k_{\text {cat }} / k_{\mathrm{m}}$, are shown in Table 2 ; for the sake of comparison, the results obtained in other published works are also tabulated. Although there are differences in the chemical nature of the substrate, in $\mathrm{pH}$ or in temperature between our experiments and those of other researchers (Campos et al., 1989; Macedo, Faro, \& Pires, 1993; Veríssimo et al., 1996), it is quite reasonable to compare the estimates of parameters obtained for all such enzymatic reactions.
The kinetic parameters estimated in this study for cardosin A are consistent with those proposed by Barros and Malcata (2002), who employed (crude) mixtures of cardosins A and B at their native ratios. The degree of affinity of cardosin A for a particular substrate $\left(K_{\mathrm{m}}\right)$ indicated that $K_{\mathrm{m}}$ was markedly lower for $\alpha$-La than for $\beta$-Lg, hence suggesting a substantially higher affinity of this enzyme for $\alpha$-La than for $\beta-\mathrm{Lg}$. For $\alpha$-La, the $K_{\mathrm{m}}$ values obtained were somewhat similar at $\mathrm{pH} 5.2$ (i.e. $0.0054 \mathrm{mM}$ ) and $\mathrm{pH} 6.0$ (i.e. $0.0033 \mathrm{mM}$ ), whereas, for $\beta-\mathrm{Lg}$, the $K_{\mathrm{m}}$ values were quite dissimilar at $\mathrm{pH} 6.0$ (i.e. $0.55 \mathrm{mM}$ ) and pH 5.2 (i.e. $0.087 \mathrm{mM}$ ). The $K_{\mathrm{m} \alpha}$ and $K_{\mathrm{m} \beta}$ values obtained in this study using pure cardosin A were of the same order of magnitude as those found for impure cardosin A (Barros \& Malcata, 2002). However, the difference of the $K_{\mathrm{m}}$ values obtained at $\mathrm{pH}$ values 5.2 and 6.0 for $\beta-\mathrm{Lg}$ was ca. 6 -fold higher, whereas it was only 2.4-fold higher when cardosin A was tested together with cardosin B in a crude mixture (Barros \& Malcata, 2002). In addition, the affinity of cardosin A for $\alpha$-La $\left(K_{\mathrm{m} \alpha}\right)$ remained unchanged between the two $\mathrm{pH}$ values studied, whereas, for $\beta-\mathrm{Lg}$, the affinity of cardosin $\mathrm{A}\left(K_{\mathrm{m} \beta}\right)$ was much higher (6-fold) at $\mathrm{pH} 5.2$ than at $\mathrm{pH}$ 6.0. When the $K_{\mathrm{m}}$ values obtained in the present work and elsewhere by Barros and Malcata (2002) were compared with those obtained by other authors (Macedo et al., 1993; Veríssimo et al., 1995), a considerable difference unfolded (see Table 2), likely due to different substrates and hydrolysis conditions. As one would expect, the $K_{\mathrm{m}}$ values are much higher than those obtained when $\kappa$-casein was used as substrate; it is indeed known that $C$. cardunculus proteases (cardosins A

Table 2

Kinetic parameter estimates that characterize the catalytic action of cardosin $\mathrm{A}$ upon $\alpha$ - $\mathrm{La}$ and $\beta$ - $\mathrm{Lg}$, and associated $95 \%$ marginal inference intervals (where available), and comparison with other studies

\begin{tabular}{|c|c|c|c|c|c|c|c|c|}
\hline Substrate & Cardosin & $T\left({ }^{\circ} \mathrm{C}\right)$ & $\mathrm{pH}$ & $K_{\mathrm{m}}(\mathrm{mM})$ & \multicolumn{2}{|l|}{$k_{\text {cat }}\left(\mathrm{s}^{-1}\right)$} & $k_{\mathrm{cat}} / K_{\mathrm{m}}\left(\mathrm{mM}^{-1} \mathrm{~s}^{-1}\right)$ & References \\
\hline Synthetic peptide & A & 37 & 4.7 & 1.08 & \multicolumn{2}{|c|}{23.6} & 21.9 & Vieira et al. (2001) \\
\hline $\begin{array}{l}\text { (Leu-Ser- } \\
\quad \text { Phe }\left(\mathrm{NO}_{2}\right)-\mathrm{Nle}- \\
\text { Ala-Leu-oMe) }\end{array}$ & B & & & 0.080 & \multicolumn{2}{|c|}{85.5} & 1057 & \\
\hline \multirow[t]{2}{*}{$\kappa$-casein } & $A+B$ & 30 & 6.4 & 0.00016 & \multicolumn{2}{|c|}{1.04} & 6500 & Campos et al. \\
\hline & & & & & $k_{\text {cat }}\left(\mathrm{s}^{-1}\right)$ & $k_{\mathrm{cat}} * f\left(\mathrm{~s}^{-1}\right)$ & & \\
\hline \multirow[t]{4}{*}{$\alpha$-Lactalbumin } & A & 55 & 5.2 & 0.039 & 0.10 & 0.045 & 2.6 & \\
\hline & & & 6.0 & 0.080 & 0.0060 & 0.0030 & 0.75 & \\
\hline & & & 5.2 & 0.038 & 0.016 & 0.090 & 0.42 & \\
\hline & B & & 6.0 & 0.020 & 0.084 & 0.041 & 4.2 & $\begin{array}{l}\text { Veríssimo et al. } \\
\text { (1995) }\end{array}$ \\
\hline \multirow[t]{4}{*}{$\beta$-Lactoglobulin } & A & 55 & 5.2 & 0.31 & 0.0020 & 0.0010 & 0.0060 & \\
\hline & & & 6.0 & 0.73 & 0.0000 & 0.0000 & 0.0000 & \\
\hline & & & 5.2 & 0.31 & 0.0070 & 0.0040 & 0.023 & \\
\hline & B & & 6.0 & 0.047 & 0.0030 & 0.020 & 0.064 & \\
\hline \multirow[t]{2}{*}{$\alpha$-Lactalbumin } & A & 55 & 5.2 & $0.054 \pm 0.00009$ & \multicolumn{2}{|c|}{$0.013 \pm 0.003$} & $2.4 \pm 0.68$ & Present study \\
\hline & & & 6.0 & $0.0033 \pm 0.00005$ & \multicolumn{2}{|c|}{$0.0022 \pm 0.00008$} & $0.66 \pm 0.26$ & \\
\hline \multirow[t]{2}{*}{$\beta$-Lactoglobulin } & & & 5.2 & $0.087 \pm 0.00006$ & 0.00018 & 0.00004 & $0.020 \pm 0.00046$ & \\
\hline & & & 6.0 & $0.55 \pm 0.02$ & \multicolumn{2}{|c|}{$0.00023 \pm 0.00002$} & $0.00042 \pm 0.000039$ & \\
\hline
\end{tabular}


and B) are particularly suited for cheesemaking, where they start coagulation by cleaving primarily the bond $\mathrm{Phe}_{105}-\mathrm{Met}_{106}$ of $\kappa$-casein (Faro, Moir, \& Pires, 1992; Macedo et al., 1993); according to Wake (1959), only אcasein is hydrolyzed during rennet coagulation and only at the aforementioned location. Furthermore, the open structure of the caseins renders them much more susceptible to proteolysis than the whey proteins, which are more globular in nature (and hence soluble in water).

Inspection of Table 2 shows a considerable discrepancy between the rates of reaction $\left(k_{\mathrm{cat}}\right)$ when $\alpha$-La and $\beta-\mathrm{Lg}$ are used as substrates. The reaction rate was at least one order of magnitude higher for $\alpha$-La, i.e. 0.013 and $0.0022 \mathrm{~s}^{-1}$, than for $\beta-\mathrm{Lg}$, i.e. 0.00018 and 0.00023 $\mathrm{s}^{-1}$, at $\mathrm{pH} 5.2$ and 6.0 , respectively. Furthermore, the order of magnitude of the values of $k, k_{\text {cat } \alpha}$ and $k_{\text {cat } \beta}$ obtained in the present work (using cardosin A only) as similar to that associated with those parameters when hydrolysis of whey proteins occurred in the presence of the crude mixture of cardosins A and B (Barros \& Malcata, 2002). In the case of $\beta-\mathrm{Lg}$, at least under the experimental conditions tested here, the experimental results show that the reaction rate remains extremely low, actually close to zero (even by 24 h), i.e. $\beta$ - $\mathrm{Lg}$ is not susceptible at all to proteolysis by cardosin A.

Determination of the $k_{\text {cat }} / K_{\mathrm{m}}$ ratio gives a combined measure of the substrate specificity and the catalytic efficiency, which permits comparison of the specificity to different substrates of a given enzyme. In our experimental runs, two substrates ( $\alpha$ - $\mathrm{La}$ and $\beta$-Lg) and only one enzyme (cardosin A) were considered, so discrimination between those two substrates is determined by the ratio $k_{\text {cat }} / K_{\mathrm{m}}$ rather than by $K_{\mathrm{m}}$ alone (Fersht, 1977). Our figures unfold a much higher catalytic efficiency $\left(k_{\text {cat }} / K_{\mathrm{m}}\right)$ of cardosin A towards $\alpha$-La than $\beta$ - $\mathrm{Lg}$, at least under the experimental conditions selected. The highest value for the ratio $\left(2.4 \mathrm{mM}^{-1} \mathrm{~s}^{-1}\right)$ was obtained for $\alpha$-La at $\mathrm{pH}$ 5.2, which was ca. 4-fold that obtained at $\mathrm{pH} 6.0$; this variation is mainly due to the large reduction of the turnover number at $\mathrm{pH}$ 6.0. The values of $k_{\mathrm{cat}} / K_{\mathrm{m}} \mathrm{ob}-$ tained for $\beta-\mathrm{Lg}$ at $\mathrm{pH} 5.2$ and 6.0, i.e. 0.0020 and $0.00042 \mathrm{mM}^{-1} \mathrm{~s}^{-1}$, respectively, revealed that this enzyme does not efficiently take up the substrate; these values are again comparable with those reported by Barros and Malcata (2002). Finally, Table 2 indicates that the purification process does not essentially affect the catalytic efficiency of this enzyme; at $\mathrm{pH} 5.2$, the catalytic efficiency toward $\alpha$-La was 2.6 and 2.4 $\mathrm{mM}^{-1} \mathrm{~s}^{-1}$, before and after the purification process, respectively (i.e. a decrease of a mere $8 \%$ ). Studies pertaining to the catalytic efficiency $\left(k_{\text {cat }} / K_{\mathrm{m}}\right)$ of $C$. cardunculus on other substrates, such as the synthetic hexapeptide (Veríssimo et al., 1995) and $\kappa$-casein (Macedo et al., 1993), revealed a great difference in behaviour. The whey proteins tested have a $k_{\text {cat }}$ value for cardosin A that is at least one hundredth (or even one thousandth) of that for $\kappa$-casein (or for the synthetic peptide), and they bind at least ten times more tightly; hence, the lower rate does not compensate for the stronger binding.

It is well established that enzymatic catalysis involves physical steps (binding of substrate to, and release of product from the active site of the enzyme) and chemical steps. When the enzymatic rates are very fast, the diffusional steps will eventually become rate-limiting. According to Fersht (1977) and Hammes and Shimmel (1970), there is a theoretical maximum for the reaction rate, where diffusion rates play a role, together with the maximum frequency at which substrate molecules will collide with each other and with the catalyst molecules; the limit for small molecules that collide with such macromolecules as enzymes is ca. $10^{5}-10^{6} \mathrm{mM}^{-1} \mathrm{~s}^{-1}$. Considering the various $k_{\mathrm{cat}} / K_{\mathrm{m}}$ ratios presented in Table 2 , one can safely assume that cardosin (either pure or in crude form) is far below this limit.

Finally, it is noteworthy that the chromophoric synthetic hexapeptide considered in Table 2 has been used and quoted by several authors as a reference substrate, either for proteolytic assay or for characterization of rennet preparations. The amino acid sequence of this peptide is related to the primary structure of bovine $\kappa$ casein on each side of the sensitive peptide bond, i.e. Phe $_{105}-$ Met $_{106}$. Studies carried out with distinct aspartic proteases have shown that they specifically catalyze the cleavage of the Phe $\left(\mathrm{NO}_{2}\right)-\mathrm{Nle}$ peptide bond in that hexapeptide (Martin, 1984). As shown by Martin (1984) and Veríssimo et al. (1995), the $K_{\mathrm{m}}$ values obtained with various aspartic proteases range in $0.019-1.08 \mathrm{mM}$, whereas those for $k_{\text {cat }}$ range in $3.4-603 \mathrm{~s}^{-1}$, so $k_{\text {cat }} / K_{\mathrm{m}}$ will eventually lie between 17 and $5260 \mathrm{mM}^{-1} \mathrm{~s}^{-1}$. The kinetic parameters found in our work for cardosin A acting on whey proteins were thus significantly lower than those obtained for other aspartic proteases acting on the synthetic hexapeptide, but differences in the labile amino acid sequence would logically account for this realization.

\section{Characterization of peptide hydrolyzates}

The evolution of the whey protein hydrolyzates formed from the original protein substrates are depicted in Figs. 3 and 4. It is possible to ascertain and quantify five major peptides, according to tricine-SDS-PAGE; their molecular weights lie between 2500 and $8000 \mathrm{Da}$. After all $\alpha$-La had been hydrolyzed, the polypeptides initially formed were hydrolyzed in turn to yield lower molecular weight peptides. By $48 \mathrm{~h}$, only one of them was still detected, with a molecular weight of ca. $6500 \mathrm{Da}$; the concomitant formation of peptides with molecular weights below $2500 \mathrm{Da}$ is not visible owing to limitations of the electrophoresis technique. Addition of more enzyme does not affect the peptide pattern, as expected, nor 


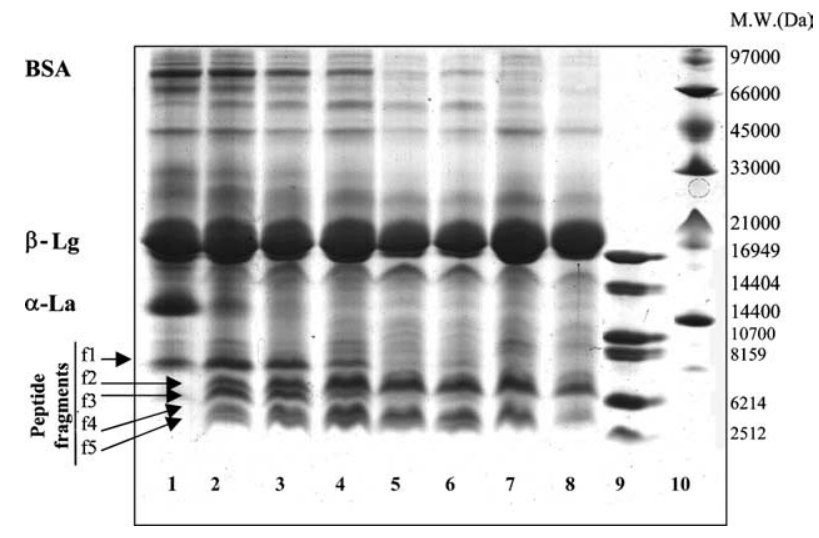

Fig. 3. Qualitative electrophoresis patterns of whey proteins, hydrolyzed by cardosin $\mathrm{A}$ at $\mathrm{pH} 5.2$ and $55^{\circ} \mathrm{C}$, at the E/S ratio $2 / 500(\mathrm{w} / \mathrm{w})$, for $5 \mathrm{~min}$ (lane 1), $1 \mathrm{~h}$ (lane 2), $2 \mathrm{~h}$ (lane 3), $5 \mathrm{~h}$ (lane 4), $8 \mathrm{~h}$ (lane 5), 12 h (lane 6), $24 \mathrm{~h}$ (lane 7) and $48 \mathrm{~h}$ (lane 8), and of low molecular weight markers (lane 9) and medium molecular weight markers (lane 10). Peptide fragments of interest are identified as f1-f5.

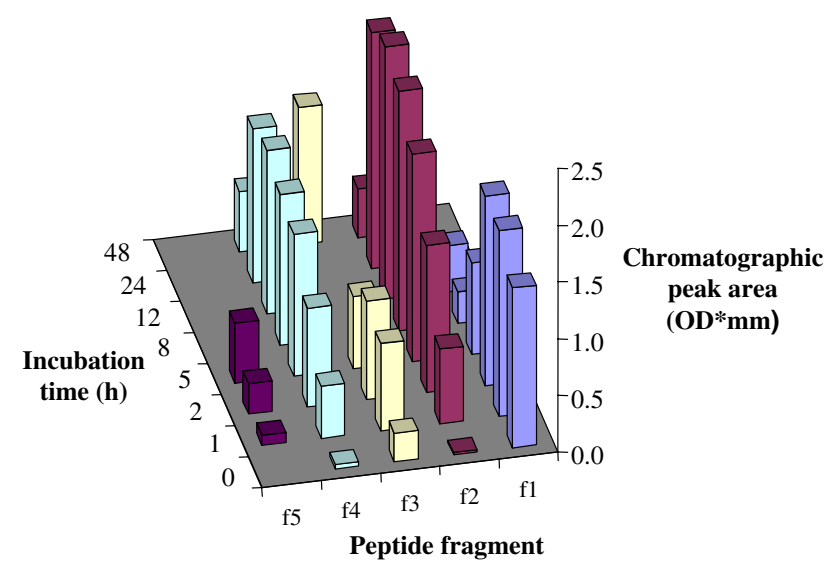

Fig. 4. Quantitative profiles of the most significant peptide fragments, detected by electrophoresis (f1-f5), released by cardosin A during whey protein hydrolysis at $\mathrm{pH} 5.2$ and $55^{\circ} \mathrm{C}$, at the E/S ratio $2 / 500(\mathrm{w} / \mathrm{w})$.

does it alter the actual specificity of cardosin A. Finally, the hydrolyzate pattern produced by cardosin A was similar at both $\mathrm{pH}$ values (data not shown).

\section{Conclusions}

The hydrolysis of $\beta-\mathrm{Lg}$ and $\alpha-\mathrm{La}$, brought about by cardosin A, was experimentally investigated in terms of two factors, namely enzyme to substrate ratio and $\mathrm{pH}$. The major two whey proteins were differently acted upon by cardosin A: $\alpha$-La was hydrolyzed at higher rates and to higher extents than $\beta$-Lg. The action of the enzyme on $\alpha$-La was, as expected, dependent on the amount of enzyme added, but this effect was more perceptible at $\mathrm{pH} 5.2$ than 6.0. The $\mathrm{pH}$ range studied seems only to affect the rate of breakdown of $\alpha$-La, which was higher at $\mathrm{pH}$ 5.2. Cardosin A was less active on both whey proteins than on $\kappa$-casein and related synthetic peptides. The reaction system, containing two proteins as substrates and one pure aspartic protease, was accurately modelled by a double-substrate, single-enzyme Michaelis-Menten model. This model may be useful for the simulation, and eventual optimization of hydrolysis of the major whey proteins of commercial interest.

\section{Acknowledgements}

Author R.M.B. received financial support from Fundação para a Ciência e a Tecnologia (Portugal), via a Ph.D. fellowship (Ref. PRAXIS XXI BD/16037/98).

\section{References}

Anon (1992). International Dairy Federation standard 157. Bovine Rennets. Determination of total milk-clotting activity. Brussels, Belgium: International Dairy Federation.

Barros, R., Ferreira, C. A., Silva, S. V., \& Malcata, F. X. (2001). Quantitative studies on the enzymatic hydrolysis of milk proteins brought about by cardosins precipitated by ammonium sulfate. Enzyme and Microbial Technology, 29, 541-547.

Barros, R., \& Malcata, F. X. (2002). Modelling the kinetics of whey protein hydrolysis brought about by enzymes from Cynara cardunculus. Journal of Agriculture and Food Chemistry, 50, 43474356.

Berridge, N. J. (1952). Some observations on the determination of activity of rennet. Analyst, 77, 57-72.

Campos, R., Guerra, R., Aguilar, M., Ventura, O., \& Camacho, L. (1989). Chemical characterization of proteases extracted from wild thistle (Cynara cardunculus). Food Chemistry, 35, 89-97.

Caracotsios, M., Stewart, W. E., \& Sorensen, J. P. (1985). GREG user's manual. Madison WI, USA: Department of Chemical Engineering, University of Wisconsin.

Faro, C.J. (1991). Purification and physico-chemical characterization of Cynara cardunculus L. protease. Ph.D. Dissertation, Universidade de Coimbra.

Faro, C. J., Moir, A. J. G., \& Pires, E. V. (1992). Specificity of a clotting enzyme extracted from Cynara cardunculus L.: Action on oxidized insulin and $\kappa$-casein. Biotechnology Letters, 14, 841-846.

Faro, C. J., Veríssimo, P. C., Lin, Y., Tang, J., \& Pires, E. V. (1995). In K. Takahashi (Ed.), Aspartic proteinases: Structure, function, biology and biomedical implications (pp. 373-377). New York: Plenum Press.

Fersht, A. R. (1977). Enzyme structure and mechanism. Reading, England: W.H. Freeman.

Hammes, G., \& Shimmel, P. (1970). In P. Boyer (Ed.), The enzymes (Vol. 2, p. 67). New York: Academic Press.

Heimgartner, U., Pietrzak, M., Geertsen, R., Bordelius, P., SilvaFigueiredo, A. C., \& Pais, M. S. S. (1990). Purification and partial characterization of milk clotting proteases from flowers of Cynara cardunculus. Photochemistry, 29, 1405-1410.

Lamas, E., Barros, R., Balcăo, V., \& Malcata, F. X. (2001). Hydrolysis of whey proteins by proteases extracted from Cynara cardunculus and immobilized onto highly activated supports. Enzyme and Microbial Technology, 28, 642-652.

Macedo, I. Q., Faro, C. J., \& Pires, E. M. (1993). Specificity and kinetics of the milk-clotting enzyme from cardoon (Cynara cardunculus L.) toward bovine $\kappa$-casein. Journal of Agriculture and Food Chemistry, 41, 1537-1540. 
Martin, P. (1984). Hydrolysis of the synthetic chromophoric hexapeptide Leu-Ser-Phe $\left(\mathrm{NO}_{2}\right)$-Nle-Ala-Leu-oMe catalyzed by bovine pepsin A. Biochimica et Biophysica Acta, 791, 28-36.

Ramalho-Santos, M., Pissara, J., Veríssimo, P., Pereira, S., Salema, R., Pires, E. V., \& Faro, C. J. (1997). Cardosin A, an abundant aspartic proteinase, accumulates in protein storage vacuoles in the stigmatic papillae of Cynara cardunculus L. Planta, 203, 204-212.

Sousa, M. J., \& Macata, F. X. (1998). Proteolysis of ovine and caprine caseins in solution by enzymatic extracts from flowers of Cynara cardunculus. Enzyme and Microbial Technology, 22, 305-314.

Tomarelli, R., Charney, M., \& Harding, M. (1949). The use of azoalbumin as a substrate in the colorimetric determination of peptic and tryptic activity. Journal of Laboratory Clinical Medicine, 34, 428-433.

Van Boekel, M. A. J. S. (1996). Statistical aspects of kinetic modeling for food science problems. Journal of Food Science, 61, 477-485, 489.
Veríssimo, P., Esteves, C., Faro, C. J., \& Pires, E. V. (1995). The vegetable rennet of Cynara cardunculus $\mathrm{L}$. contains two proteinases with chymosin and pepsin-like specificities. Biotechnology Letters, 17, 621-626.

Veríssimo, P., Faro, C. J. C., Moir, A. J. C., Yingzhang, L., Tang, J., $\&$ Pires, E. (1996). Purification, characterization and partial amino acid sequencing of two new aspartic proteases from fresh flowers of Cynara cardunculus L. European Journal of Biochemistry, 235, 762768.

Vieira, M., Pissara, J., Veríssimo, P., Castanheira, P., Costa, Y., Pires, E., \& Faro, C. (2001). Molecular cloning and characterization of cDNA encoding cardosin $\mathrm{B}$, an aspartic proteinase accumulating extracellularly in the transmitting tissue of Cynara cardunculus L. Plant Molecular Biology, 45, 529-539.

Wake, R. G. (1959). Studies of casein V. The action of rennin on casein. Australian Journal of Biological Sciences, 12, 479-489. 